\title{
Cost-Effectiveness of Prehospital versus Inhospital Thrombolysis in Acute Myocardial Infarction
}

\author{
Denizar Vianna Araújo7, Bernardo Rangel Tura², Antonio Luiz Brasileiro², Heitor Luz Neto³, Ana Luiza Braz Pavão4, \\ Vanessa Teich \\ Universidade do Estado do Rio de Janeiro ${ }^{1}$, Instituto Nacional de Cardiologia - Ministério da Saúde², Instituto Nacional de Traumatologia e Ortopedia \\ - Ministério da Saúde 3 , Medlnsight - Decisions in Health Care ${ }^{4}$, Rio de Janeiro, RJ, Brasil
}

\section{Summary}

Background: There is evidence that prehospital thrombolysis improves the outcome in ST-elevation myocardial infarction (STEMI).

Objective: This study aimed at comparing the cost-effectiveness of prehospital compared to inhospital thrombolysis for STEMI from the National Health System perspective.

Methods: A decision-analytic model was used to compare these two strategies. The study endpoint was life-years gained. Resource use and costs were estimated from the National Health System perspective. The Decision tree and Markov Model were constructed using the results of published clinical trials. Costs were expressed in Reais (R\$), for the year 2005.

Results: For a time horizon of 20 years, prehospital thrombolysis had an average life expectancy of 11.48 years and inhospital thrombolysis had an average life expectancy of 11.32 years. Costs were $\mathbf{R} \mathbf{5 , 6 4 0}$ for prehospital thrombolysis and R\$ 5,816 for inhospital thrombolysis. Inhospital thrombolysis led to an additional cost of R\$ 176 per patient. Prehospital thrombolysis led to additional 0.15 years of life-expectancy gain compared with inhospital thrombolysis.

Conclusion: This model suggests that, from the National Health System perspective, implementing prehospital thrombolysis for ST-elevation myocardial infarction (STEMI) may lead to extra survival and fewer costs when compared to inhospital thrombolysis. (Arq Bras Cardiol 2008; 90(2) : 91-98)

Key words: Cost-effectiveness evaluation; thrombolytic therapy; myocardial infarction.

\section{Introduction}

The time spent between the onset of pain and the thrombolytic therapy remains one of the determinant factors in the mortality of ST-elevation myocardial infarction (STEMI) ${ }^{1}$.

Despite the technological advances and increased awareness of the population regarding the necessity of early treatment in the course of an acute myocardial infarction $(\mathrm{AMI})$, the time spent between the onset of symptoms and the start of the thrombolytic therapy remains unaltered, with a median of 2.5 to 3 hours, in a favorable scenario of the population access to emergency services ${ }^{2}$.

Some states in Brazil have a high mortality due to ischemic heart disease, despite the available hospital beds at the Sistema Único de Saúde (SUS), the Brazilian Public Health System. The capital of the state of Rio de Janeiro has the largest public hospital network of the country;

\footnotetext{
Mailing address: Denizar Vianna Araújo •

Av. Visconde Albuquerque, 1400/501 - Leblon - 22450-000, Rio de Janeiro,

RJ - Brasil

E-mail: denizar@cardiol.br

Received on 05/06/07; revised article received on 07/27/07; accepted on 10/15/07.
}

however, the state has the second highest specific mortality rate due to ischemic heart disease in Brazil (68.44/100,000 inhabitants) ${ }^{3}$.

Morrison and cols. carried out a meta-analysis on the hospital mortality due to AMI, with the use of thrombolysis performed in the prehospital environment versus inhospital thrombolysis ${ }^{4}$. The authors analyzed six randomized controlled trials, with a total of 6,434 patients and showed that the strategy of thrombolytic infusion in the prehospital environment, carried out by physicians or paramedics, allowed the anticipation of the thrombolytic therapy by 60 minutes [104(7) minutes in pre versus 162(16) minutes in inhospital; $p=0,007$, with a global reduction of $17 \%$ in mortality, when compared to the inhospital treatment (odds ratio $0.83 ; 95 \% \mathrm{Cl}, 0.70-0.98$ ). Table 1 summarizes the characteristics of the six randomized controlled clinical trials of the meta-analysis.

Brasileiro remarked in a recent editorial on the characteristics of the Mobile Emergency Care Service (MECS) ${ }^{5}$. This service was launched in September 2003 as the main component of the National Policy of Emergency Care of SUS. Despite the effort, a systematized program to offer thrombolytic therapy in the acute phase of myocardial infarction is not fully structured 
Table 1 - Characteristics of the controlled randomized clinical assays used in the meta-analysis of Morrison and cols.

\begin{tabular}{|c|c|c|c|c|c|c|c|c|}
\hline \multirow[b]{3}{*}{ Study. Year } & \multicolumn{8}{|c|}{ Time between symptom onset and thrombolysis } \\
\hline & \multirow[b]{2}{*}{ Provider } & \multicolumn{4}{|c|}{ Mean (SD) minutes } & \multicolumn{3}{|c|}{ All causes of hospital death } \\
\hline & & $\begin{array}{c}\text { Type of } \\
\text { Thrombolytic }\end{array}$ & Pre- hospital & Inhospital & $\begin{array}{l}\text { Difference or } \\
p \text { value }\end{array}$ & $\begin{array}{l}\text { Prehosp } \\
\text { total N }\end{array}$ & $\begin{array}{l}\text { Inhosp } \\
\text { total N }\end{array}$ & $\begin{array}{c}\text { OR } \\
(95 \% \mathrm{Cl})\end{array}$ \\
\hline MITI Trial. 1993 & Paramedic & rt-PA & $\begin{array}{c}\text { 92(58); } \\
\text { 77[median] }\end{array}$ & $\begin{array}{c}\text { 120(49); } \\
\text { 110[median] }\end{array}$ & $\begin{array}{c}P<.001 ; 33 \mathrm{~min} \\
(18)\end{array}$ & $10 / 175$ & $15 / 175$ & $\begin{array}{c}0.69 \\
(0.30-1.57)\end{array}$ \\
\hline $\begin{array}{l}\text { EMIP Group. } \\
1993\end{array}$ & MICU & Anistreplase & 130[median] & 190[median] & $\begin{array}{c}55 \mathrm{~min} \\
\text { [median] }\end{array}$ & $251 / 2750$ & $284 / 2719$ & $\begin{array}{c}0.86 \\
(0.72-1.03)\end{array}$ \\
\hline $\begin{array}{l}\text { GREAT study. } \\
1992\end{array}$ & GPs & Anistreplase & $\begin{array}{c}\text { 101[25-360] } \\
\text { median } \\
\text { [variation] }\end{array}$ & $\begin{array}{c}\text { 240[80-540] } \\
\text { median } \\
\text { [variation] }\end{array}$ & $\begin{array}{c}\text { 130[40-370] } \\
\text { median } \\
\text { [variation] }\end{array}$ & $11 / 163$ & $17 / 148$ & $\begin{array}{c}0.56 \\
(0.25-1.23)\end{array}$ \\
\hline Roth et al. 1990 & $\mathrm{MICU}$ & rt-PA & $94(36)$ & $137(45)$ & $\mathrm{P}<.001$ & $4 / 72$ & $3 / 44$ & $\begin{array}{c}0.80 \\
(0.17-3.77)\end{array}$ \\
\hline $\begin{array}{l}\text { Schofer et al. } \\
1990\end{array}$ & MICU & Urokinase & $85(51)$ & $137(50)$ & $\mathrm{P}<.001$ & $1 / 40$ & $2 / 38$ & $\begin{array}{c}0.46 \\
(0.04-5.31)\end{array}$ \\
\hline $\begin{array}{l}\text { Castaigne et al. } \\
1989\end{array}$ & MICU & Anistreplase & 131 [median] & 180 [median] & $60 \min$ & $3 / 57$ & $3 / 43$ & $\begin{array}{c}0.74 \\
(0.14-3.86)\end{array}$ \\
\hline
\end{tabular}

MITI Trial - Myocardial Infarction Triage and Intervention; EMIP Group - The European Myocardial Infarction Project Group; GREAT study - Grampian Region Early Anistreplase Trial; MICU - Mobile Intensive Care Unit; GPS - General Practitioners; OR - Odds Ratio; Cl - Confidence Interval; Source: Morrison et al. 2000.

at national level.

The aim of this study was to compare the cost-effectiveness of prehospital compared to inhospital thrombolysis in patients with STEMI being treated by the SUS, in order to contribute with health policy plans in the implementation of this service at the MECS.

\section{Methods}

The models of the analysis of clinical decision are designed by the chronological sequence of problem identification; structuring of the problem (decision tree and Markov model); parameterization of the decision model (probability of occurrence of outcomes, according to the critical analysis of the literature) and analysis of the model (cost estimate, outcomes and risks) ${ }^{6}$.

An analytical model of decision, of the decision-tree type, and a Markov model were designed to evaluate and compare the costs and clinical effectiveness of prehospital versus inhospital thrombolysis in patients with STEMI, from the National Health System perspective. Figure 1 shows the decision tree with the probability data on AMI treatment evolution and the cost data.

The cost-effectiveness analysis measures the cost in monetary units divided by a non-monetary unit, called the natural unit, for instance, "years of life saved". It allows the calculation of the cost incurred by unit of effectiveness. A health intervention is said to be cost-effective if it produces a clinical benefit that is justifiable for its cost.

The evolution probabilities of the decision tree were obtained from the Economic Model developed by Vale et $\mathrm{al}^{7}$, from the Randomized Controlled Clinical Trial GREAT ${ }^{3}$, used in the meta-analysis carried out by Morrison et $\mathrm{al}^{4}$.

The life expectancy data for the Markov model were obtained from the Brazilian Institute of Geography and Statistics (IBGE) table of mortality and adjusted for the different states using the proportions extracted from the GREAT study ${ }^{8}$.

Vale et $\mathrm{al}^{7}$ created a model of decision analysis to compare cost and effectiveness of thrombolysis carried out in the prehospital environment versus the inhospital one for the treatment of $\mathrm{AMI}^{7}$. The effectiveness was measured in "years of life gained", with data obtained from the GREAT study, carried out in Scotland between 1988 and 1991. The thrombolytic used in the prehospital environment was Anistreplase. At the inhospital environment, Alteplase and heparin (for AMI of the anterior wall) and streptokinase and heparin (for the other cases) were used. The authors found a gain of 0.09 years for the prehospital treatment compared to the life expectancy in the inhospital environment, with an incremental cost of $£ 61$ per patient in the prehospital environment.

\section{Probability data of event occurrence}

The decision-tree of the model predicts that part of the population can die before receiving medical treatment, in the prehospital as well as in the inhospital environment and that, considering the diagnostic accuracy of the available tests to confirm the AMI, the patients are diagnosed as true positive, false positive, true negative and false negative. There are no data in the literature comparing the accuracy of the diagnosis attained at the prehospital versus the one attained at the inhospital environment. Considering that the diagnostic accuracy in the prehospital is lower than that at the inhospital environment and taking into account the values of true- and false-positive results in the inhospital environment, a conversion factor of $75 \%$ was adopted to calculate these parameters for the prehospital environment. The patients with a true-positive or false-negative diagnosis are also prone to reinfarction. The 30-day reinfarction rate for patients with AMI that did not receive thrombolytic therapy was $16 \%{ }^{9}$. Table 2 shows the probabilities used in the model.

In this model, the patients diagnosed with AMI can be 


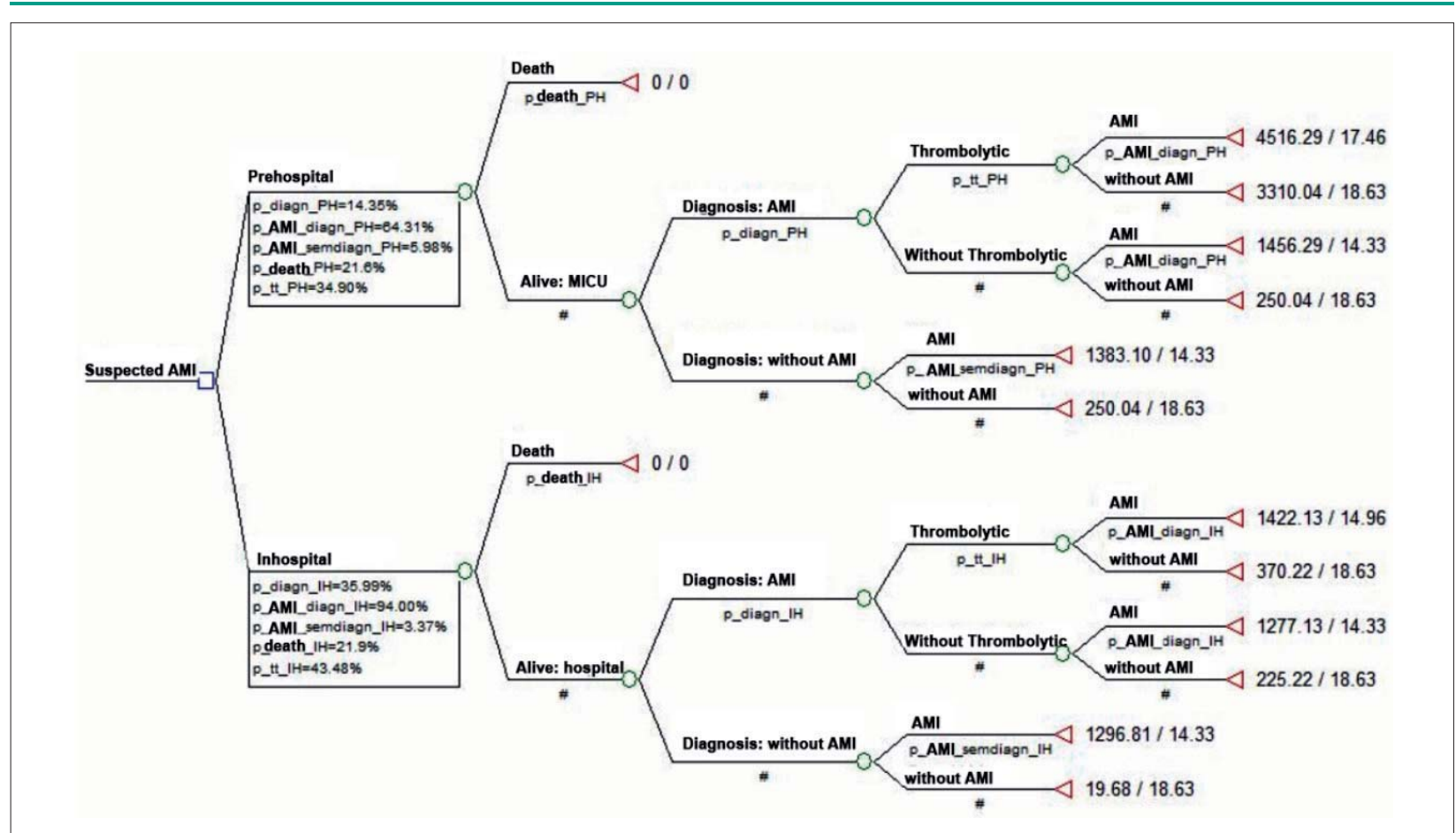

Figure 1 - Tree-diagram of prehospital versus inhospital thrombolysis in patients with ST-elevation Myocardial Infarction (STEMI) in the Public Health System scenario. Legend: AMI - acute myocardial infarction; p - Probability; PH - Prehospital; IH - Inhospital; MICU - Mobile Intensive Care Unit.

Table 2 - Strategy probabilities in the Prehospital and Inhospital thrombolysis

\begin{tabular}{|c|c|c|}
\hline \multicolumn{3}{|c|}{ Prehospital } \\
\hline Death before treatment & $21.60 \%$ & $\mathrm{p}$ (death) \\
\hline$\%$ patients diagnosed with $\mathrm{AMI}$ & $14.35 \%$ & $\mathrm{p}$ (AMl diagnosis) \\
\hline AMI probability & $20.00 \%$ & $\mathrm{p}(\mathrm{AMI})$ \\
\hline AMI probability considering the diagnosis was positive & $64.31 \%$ & p(AMl / AMI diagnosis) \\
\hline AMI probability considering the diagnosis was negative & $5.98 \%$ & $\mathrm{p}(\mathrm{AMI} / \mathrm{absence}$ of AMI) \\
\hline True positive & $46.13 \%$ & p(AMI diagnosis / AMI) \\
\hline False positive & $6.40 \%$ & $\mathrm{p}(\mathrm{AMI}$ diagnosis / absence of AMI) \\
\hline Conversion factor & $75.00 \%$ & Analysis of sensitivity \\
\hline$\%$ patients with AMI diagnosis that received thrombolytic & $34.90 \%$ & \\
\hline 30-day reinfarction rate & $5.80 \%$ & \\
\hline \multicolumn{3}{|c|}{ Inhospital } \\
\hline Death before treatment & $21.90 \%$ & $p$ (death) \\
\hline$\%$ patients diagnosed with $\mathrm{AMI}$ & $35.99 \%$ & $\mathrm{p}$ (AMl diagnosis) \\
\hline AMI probability & $55.00 \%$ & $\mathrm{p}(\mathrm{AMI})$ \\
\hline AMI probability considering the diagnosis was positive & $94.00 \%$ & p(AMI / AMI diagnosis) \\
\hline AMI probability considering the diagnosis was negative & $3.37 \%$ & $\mathrm{p}(\mathrm{AMI} / \mathrm{absence}$ of AMI) \\
\hline True positive & $61.50 \%$ & p(AMI diagnosis / AMI) \\
\hline False positive & $4.80 \%$ & $\mathrm{p}(\mathrm{AMI}$ diagnosis / absence of AMI) \\
\hline$\%$ patients with AMI diagnosis that received thrombolytic & $43.48 \%$ & \\
\hline 30-day reinfarction rate & $10.00 \%$ & \\
\hline
\end{tabular}

Source: Wallentin et al 2003 and Vale et al 20047.; AMI - Acute Myocardial Infarction. 
eligible or not for the thrombolytic therapy. If they receive the thrombolytic, the patients are treated with Tenecteplase or Streptokinase, in the pre- and inhospital environment, respectively. Tenecteplase was chosen for the prehospital treatment as it is the only bolus thrombolytic agent available in Brazil, a condition that allows its use outside the hospital environment. Streptokinase was the choice for the inhospital treatment as its acquisition cost is the lowest for the SUS. The patients who did not receive the thrombolytic agent are treated with adjunct and support therapy recommended by the directives of the Brazilian Society of Cardiology ${ }^{10}$.

The patients treated at the prehospital environment are referred to the hospital for continuing care. The mean hospital stay duration is 8 days (mean hospital stay due to AMI in the SUS in 2005) for the true-positive patients, whether they received thrombolytic or not. The false-negative patient will return subsequently to the hospital and will be later diagnosed and treated with AMI.

The Directives on the Treatment of Acute Myocardial Infarction were adopted to estimate the resources used at the prehospital and inhospital treatment strategies ${ }^{10}$. The resources were analyzed according to the government prices practiced in the year 2005, in the treatment of AMI, from the perspective of the SUS ${ }^{11}$.

\section{Cost data used in the model}

The components of the direct costs analyzed in the model were the costs of prehospital treatment carried out by the MECS (Mobile Emergency Care Service) ${ }^{12}$, emergency care at the hospital, hospital stay costs, complementary exams, outpatient follow-up appointments and outpatient medications. The unitary costs are shown in Table 3.

The effectiveness unit used in the model was "years of life saved", using as reference the life expectancy established at the decision model created by Vale et $\mathrm{al}^{7}$, of which value was corrected for the mortality table of the Brazilian population published by the Brazilian Institute of Geography and Statistics (IBGE) in $2005^{13}$. The cost of the reinfarction and follow-up considered in the model are shown in Table 4.

The effectiveness unit measured in the model was "years of life saved", using as reference the life expectancy established in the Economic Model developed by Vale et $\mathrm{al}^{7}$, derived from Randomized Controlled Clinical Trial GREAT ${ }^{8}$, of which value was corrected for the mortality table of the Brazilian population at 63 years of age, in the year 2005, published by the IBGE in $2005^{11}$.

The expected life expectancy values were converted into annual mortality rates. Subsequently, the conversion factors for the different conditions of the model were calculated, as shown in Table 5.

These factors were used to convert the mortality probabilities found in the mortality table of IBGE to the different conditions of the Markov model. The model supposed that a patient with a suspected AMI, albeit without confirmation of the AMI, would have the mean life expectancy of the Brazilian individual.

All through the Markov model, with a one-year cycle duration, the patients could die or remain at the initial
Table 3 - Cost units involved in the prehospital and inhospital treatment

\begin{tabular}{|c|c|}
\hline Honoraries & Cost R\$ \\
\hline Medical visit & 7.55 \\
\hline Advanced support team - MICU & 76.39 (p/ hour) \\
\hline Medical Regulation Center of MICU & 52,76 (p/ hour) \\
\hline \multicolumn{2}{|l|}{ Hospital admission } \\
\hline Admission costs (honoraries, daily rate, medicaments) & $1,026.31$ \\
\hline \multicolumn{2}{|l|}{ Interventionist Procedure } \\
\hline Coronary angioplasty (1 vessel) - total cost & $4,989.95$ \\
\hline \multicolumn{2}{|l|}{ Complementary Exams } \\
\hline Enzymes (CK-MB, troponin) & 16.48 \\
\hline Electrocardiogram & 3.20 \\
\hline Echocardiogram & 20.48 \\
\hline 24-hour Holter & 8.57 \\
\hline Ergometric Test & 19.80 \\
\hline Myocardial scintigraphy & 125.97 \\
\hline \multicolumn{2}{|l|}{ Medicaments } \\
\hline Nasal oxygen $51 / \min (2 \mathrm{hrs})$ & 21.88 \\
\hline Morphine sulphate 2 to $8 \mathrm{mg}$ & 0.90 \\
\hline Mononitrate- 5 isosorbide $5 \mathrm{mg}$ & 0.03 \\
\hline Isosorbide 40mg & 0.54 \\
\hline ASA 100 mg & 0.02 \\
\hline ASA 325 mg & 0.03 \\
\hline Propranolol 20 mg & 0.08 \\
\hline Captopril 25mg & 0.03 \\
\hline Simvastatin 40mg & 0.07 \\
\hline Injectable Streptokinase (1.500.000 UI) & 250.00 \\
\hline Tenecteplase & $3,770.77$ \\
\hline Fractioned Heparin (") & 345.93 \\
\hline Non-Fractioned Heparin ${ }^{(+)}$ & 16.90 \\
\hline
\end{tabular}

Source: Sistema de Informações Ambulatoriais e Hospitalares - SAS/ DATASUS - 20053; Banco de preços do Ministério da Saúde ${ }^{11}$; Secretaria da Saúde do Estado da Bahia APH Móvel - SAMU ${ }^{12}$; ( ${ }^{*}$ ) Considering the use of $30 \mathrm{mg}$ in bolus followed by $1 \mathrm{mg} / \mathrm{kg}$ every 12 hours for 7 days, for a patient with a medium weight of $70 \mathrm{~kg}$. Cost of one vial with $20 \mathrm{mg}=R \$ 6.85 ;\left(^{+}\right)$ Considering the use of $60 \mathrm{Ul} / \mathrm{kg}$ in bolus followed by de $12 \mathrm{UI} / \mathrm{Kg} / \mathrm{hour}$ for 48 hours. Cost of one vial with $25.000 \mathrm{UI}=R \$ 9.49$.

condition. The results were calculated for the time horizon of one year and twenty years.

The analysis of the cost-effectiveness performed was established based on the increment cost-effectiveness ratio (ICER), calculated by the division of the mean difference of costs between the prehospital vs the inhospital thrombolysis, by the difference of effectiveness (years of life saved). The decision tree and the statistical analyses were performed by the TreeAge Pro Healthcare software [TreeAge Software, Inc. MA, USA (version 2005)]. The Markov model was constructed with the Microsoft Excel ${ }^{\circledR}$ software. 


\section{Original Article}

Table 4 - Cost of the treatment of the reinfarction, of the annual follow-up post-AMI and the annual follow-up post-suspected AMI

\begin{tabular}{|c|c|c|c|}
\hline \multicolumn{4}{|c|}{ Cost of Reinfarction } \\
\hline Cost of Reinfarction & & & $\mathrm{R} \$ 6,216.56$ \\
\hline Cardiac enzymes & $R \$ 16.48$ & 1 & $R \$ 16.48$ \\
\hline Electrocardiogram & $\mathrm{R} \$ 3.20$ & 9 & $\mathrm{R} \$ 28.80$ \\
\hline Echocardiogram & $R \$ 20.48$ & 1 & $\mathrm{R} \$ 20.48$ \\
\hline 24-hrs Holter & $\mathrm{R} \$ 8.57$ & 1 & $\mathrm{R} \$ 8.57$ \\
\hline Myocardial scintigraphy & $\mathrm{R} \$ 125.97$ & 1 & $\mathrm{R} \$ 125.97$ \\
\hline Coronary angioplasty (1 vessel) & $\mathrm{R} \$ 4,989.95$ & 1 & $\mathrm{R} \$ 4,989.95$ \\
\hline Hospital admission & $\mathrm{R} \$ 1,026.31$ & 1 & $\mathrm{R} \$ 1,026.31$ \\
\hline \multicolumn{4}{|c|}{ Cost of the annual follow-up post-AMI } \\
\hline Follow-up post AMI & & & $\mathrm{R} \$ 507.52$ \\
\hline Medical visit & $\mathrm{R} \$ 7.55$ & 6 & $R \$ 45.30$ \\
\hline Electrocardiogram & $\mathrm{R} \$ 3.20$ & 6 & $R \$ 19.20$ \\
\hline Echocardiogram & $\mathrm{R} \$ 20.48$ & 1 & $\mathrm{R} \$ 20.48$ \\
\hline 24-hrs Holter & $\mathrm{R} \$ 8.57$ & 1 & $\mathrm{R} \$ 8.57$ \\
\hline Myocardial scintigraphy & $\mathrm{R} \$ 125.97$ & 1 & $\mathrm{R} \$ 125.97$ \\
\hline Cardiac rehabilitation post-AMI & $\mathrm{R} \$$ - & 1 & $\mathrm{R} \$$ - \\
\hline Acetylsalicylic acid $200 \mathrm{mg}$ & $\mathrm{R} \$ 0.04$ & 360 & $\mathrm{R} \$ 14.40$ \\
\hline Propranolol $80 \mathrm{mg}$ & $\mathrm{R} \$ 0.03$ & 360 & $R \$ 10.80$ \\
\hline Captopril 100mg & $\mathrm{R} \$ 0.12$ & 360 & $\mathrm{R} \$ 43.20$ \\
\hline Isosorbide 40mg & $\mathrm{R} \$ 0.54$ & 360 & $\mathrm{R} \$ 194.40$ \\
\hline Simvastatin 40mg & $\mathrm{R} \$ 0.07$ & 360 & $\mathrm{R} \$ 25.20$ \\
\hline \multicolumn{4}{|c|}{ Cost of the follow-up post-false AMI } \\
\hline Follow-up post- suspected AMI & & & $\mathrm{R} \$ 418.64$ \\
\hline Medical visit & $\mathrm{R} \$ 7.55$ & 6 & $\mathrm{R} \$ 45.30$ \\
\hline Electrocardiogram & $\mathrm{R} \$ 3.20$ & 6 & $\mathrm{R} \$ 19.20$ \\
\hline 24-hrs Holter & $\mathrm{R} \$ 8.57$ & 1 & $\mathrm{R} \$ 8.57$ \\
\hline Myocardial scintigraphy & $\mathrm{R} \$ 125.97$ & 1 & $\mathrm{R} \$ 125.97$ \\
\hline Acetylsalicylic acid $200 \mathrm{mg}$ & $\mathrm{R} \$ 0.04$ & 360 & $\mathrm{R} \$ 14.40$ \\
\hline Propranolol $80 \mathrm{mg}$ & $\mathrm{R} \$ 0.03$ & 360 & $R \$ 10.80$ \\
\hline Isosorbide 40mg & $\mathrm{R} \$ 0.54$ & 360 & $\mathrm{R} \$ 194.40$ \\
\hline
\end{tabular}

AMI - Acute Myocardial Infarction.

Table 5 - Annual mortality rates and conversion factors by state

\begin{tabular}{lccc}
\hline States & $\begin{array}{c}\text { Life } \\
\text { expectancy }\end{array}$ & $\begin{array}{c}\text { Annual } \\
\text { mortality rate } \\
(\%)\end{array}$ & $\begin{array}{c}\text { Conversion } \\
\text { factor(\%) }\end{array}$ \\
\hline $\begin{array}{l}\text { W/o AMl / w/0 } \\
\text { thrombolytic }\end{array}$ & 18.63 & 0.0536769 & $0.00 \%$ \\
$\begin{array}{l}\text { Prehospital thrombolytic } \\
\text { Inhospital thrombolytic }\end{array}$ & 17.46 & 0.0572622 & $6.68 \%$ \\
$\begin{array}{l}\text { With AMl / w/o } \\
\text { thrombolytic }\end{array}$ & 14.96 & 0.0668345 & $24.51 \%$ \\
\hline
\end{tabular}

AMI - Acute Myocardial Infarction.

\section{Results}

The model of the decision tree calculated costs for the different model outcomes considering the patient's initial characteristics, for both treatment strategies. Table 6 summarizes such costs, which correspond to the initial treatment approach and treatment of the true and false suspected AMI.

The subsequent Markov model considers that the patients initiate the model distributed by the conditions according to the proportions shown in Table 6. According to the condition, different annual follow-up costs are attributed to the patients' follow-up. Throughout the model, the patients die through 
Original Article

Table 6 - Cost estimate of the different clinical pictures in the pre-hospital and inhospital treatment

\begin{tabular}{|c|c|c|c|c|c|c|c|}
\hline \multicolumn{8}{|c|}{ Cost estimate of the different clinical pictures in the pre-hospital treatmen } \\
\hline Status & $\%$ Final & Cost R\$ & $\begin{array}{c}\text { Life } \\
\text { expectancy } \\
\text { (yrs) }\end{array}$ & $\begin{array}{c}\text { Cost of } \\
\text { follow-up } \\
\text { R\$ }\end{array}$ & $\begin{array}{l}\text { Reinfarction } \\
\text { incidence }\end{array}$ & $\begin{array}{c}\text { Cost of } \\
\text { reinfarction } \\
\mathrm{R} \$\end{array}$ & $\begin{array}{l}\text { Cost of } \\
\text { lifetime } \\
\text { R\$ }\end{array}$ \\
\hline Death before treatment & $21.60 \%$ & - & 0 & - & $0 \%$ & - & - \\
\hline AMI with thrombolytic & $2.52 \%$ & $5,572.83$ & 17.46 & $8,863.09$ & $6 \%$ & 360.56 & $14,796.47$ \\
\hline AMI w/o thrombolytic and no diagnosis & $4.01 \%$ & $6,322.53$ & 14.33 & $7,274.90$ & $16 \%$ & 994.65 & $14,592.08$ \\
\hline AMI w/o thrombolytic with diagnosis & $4.71 \%$ & $1,456.13$ & 14.33 & $7,274.90$ & $16 \%$ & 994.65 & $9,725.68$ \\
\hline No AMl and with thrombolytic & $1.40 \%$ & $4,366.58$ & 18.63 & $7,799.26$ & $0 \%$ & - & $12,165.84$ \\
\hline No IAM, no thrombolytic and no diagnosis & $63.14 \%$ & 105.97 & 18.63 & $7,799.26$ & $0 \%$ & - & $7,905.23$ \\
\hline No AMI, no thrombolytic with diagnosis & $2.61 \%$ & 249.88 & 18.63 & $7,799.26$ & $0 \%$ & - & $8,049.14$ \\
\hline \multicolumn{8}{|l|}{ No AMI, no thrombolytic and with diagnosis } \\
\hline \multicolumn{8}{|c|}{ Cost estimate of the different clinical pictures in the inhospital treatment } \\
\hline Status & $\begin{array}{c}\text { Final } \\
\text { Proportion }\end{array}$ & Cost R\$ & $\begin{array}{c}\text { Life } \\
\text { expectancy } \\
\text { (yrs) }\end{array}$ & $\begin{array}{c}\text { Cost of } \\
\text { follow-up } \\
\text { R\$ }\end{array}$ & $\begin{array}{l}\text { Reinfarction } \\
\text { incidence }\end{array}$ & $\begin{array}{c}\text { Cost of } \\
\text { reinfarction } \\
\mathrm{R} \$\end{array}$ & $\begin{array}{l}\text { Cost of } \\
\text { lifetime } \\
\text { R\$ }\end{array}$ \\
\hline Death before treatment & $21.90 \%$ & - & 0 & - & $0 \%$ & - & - \\
\hline AMI with thrombolytic & $11.49 \%$ & $1,543.87$ & 14.96 & $7,593.68$ & $10 \%$ & 621.66 & $9,759.20$ \\
\hline AMI w/o thrombolytic and no diagnosis & $1.69 \%$ & $6,236.24$ & 14.33 & $7,274.90$ & $16 \%$ & 994.65 & $14,505.79$ \\
\hline AMI w/o thrombolytic with diagnosis & $14.93 \%$ & $1,276.97$ & 14.33 & $7,274.90$ & $16 \%$ & 994,65 & $9,546.52$ \\
\hline No AMI and with thrombolytic & $0.73 \%$ & 491.96 & 18.63 & $7,799.26$ & $0 \%$ & - & $8,291.22$ \\
\hline No AMI, no thrombolytic and no diagnosis & $48.31 \%$ & 19.68 & 18.63 & $7,799.26$ & $0 \%$ & - & $7,818.94$ \\
\hline No AMI, no thrombolytic and with diagnosis & $0.95 \%$ & 225.06 & 18.63 & $7,799.26$ & $0 \%$ & - & $8,024.32$ \\
\hline
\end{tabular}

AMI - Acute Myocardial Infarction.

different mortality rates. The cost results and mean life expectancy for the time horizon of one year and 20 years were calculated.

Table 7 summarizes the results of the estimate of gain in life expectancy and of the costs in the comparative analysis of patients treated at the prehospital versus the inhospital environment, from the perspective of 1 and 20 years, respectively.

The analysis of cost-effectiveness, when comparing the prehospital versus the inhospital thrombolysis, in a time horizon of one year, showed a cost decrease of $\mathrm{R} \$ 44.90$. For the time horizon of 20 years, the decrease was $\mathrm{R} \$ 176.72$ (present value of the future costs). This condition of lower cost with higher effectiveness, in the comparison between the two treatment strategies, is called dominant.

\section{Discussion}

Despite the technological advances and increased awareness of the population regarding the necessity of early treatment in the course of an acute myocardial infarction (AMI), the time spent between the onset of symptoms and the start of the thrombolytic therapy remains unaltered. This scenario is a matter of concern in the main Brazilian capitals, where the transportation of the patient with a suspected AMI is complicated by logistic issues that prevent the rapid access to the thrombolytic therapy.
Table 7 - - Result of the cost-effectiveness analysis in the comparison of pre-hospital and in-hospital thrombolysis in the treatment of Acute Myocardial Infarction, for a time-horizon of 1 and 20 years

\begin{tabular}{|c|c|c|c|}
\hline \multicolumn{4}{|c|}{ Time-horizon of 1 year } \\
\hline Strategy & Cost & $\begin{array}{c}\text { Life } \\
\text { expectancy } \\
\text { (in } 1 \text { year) }\end{array}$ & ICER \\
\hline Pre-hospital & $\mathrm{R} \$ 1,025.45$ & 0.7696 & \\
\hline Inhospital & $\mathrm{R} \$ 1,070.34$ & 0.7661 & \\
\hline Increment & $(\mathrm{R} \$ 44.90)$ & 0.0035 & Dominant \\
\hline \multicolumn{4}{|c|}{ Time-horizon of 20 years } \\
\hline Strategy & Cost & $\begin{array}{c}\text { Life } \\
\text { expectancy } \\
\text { (in } 20 \text { years) }\end{array}$ & ICER \\
\hline Pre-hospital & $\mathrm{R} \$ 5,640.04$ & 11.4853 & \\
\hline Inhospital & $\mathrm{R} \$ 5,816.76$ & 11.3268 & \\
\hline Increment & $(\mathrm{R} \$ 176.72)$ & 0.1585 & Dominant \\
\hline
\end{tabular}

ICER - increment cost-effectiveness ratio.

The meta-analysis performed by Morrison et al ${ }^{4}$ (level 1 evidence $^{14}$ ) showed that the strategy of thrombolytic infusion in the prehospital environment, carried out by physicians or paramedics, allowed the anticipation of the thrombolytic therapy by 60 minutes, with a global reduction of $17 \%$ in 


\section{Original Article}

mortality, when compared to the inhospital treatment (odds ratio $0.83 ; 95 \% \mathrm{Cl}, 0.70-0.98$ ).

The European Society of Cardiology, American Heart Association and Canadian Cardiovascular Society recommend, in their respective directives of AMI treatment, the prehospital treatment strategy ${ }^{15-17}$.

The coefficients of mortality by AMI in the Brazilian cities, stratified by age, show risk profiles that are different from those observed in other countries ${ }^{18}$. Approximately $50 \%$ of the male deaths due to coronary artery disease occur at the age range $<65$ years. In the United States, Cuba and England, this percentage is around $25 \%{ }^{19}$. This high mortality at younger age ranges represents an important socio-economic impact for Brazil, as it promotes an early withdrawal of the individual from the labor market. A hypothesis for such high mortality is the lack of access to treatment during the acute phase of the myocardial infarction.

We performed a cost-effectiveness analysis from the Brazilian National Health System perspective, to compare the strategy of thrombolytic infusion in a prehospital environment carried out by the MECS, versus the conventional inhospital treatment. Our objective was to evaluate whether the initial cost with the logistic apparatus of the MECS and the costs of the bolus thrombolytic agent would result in a decrease in the subsequent costs such as the need for hospital readmission and interventionist procedures through the better management of $\mathrm{AMI}$ in the pre-hospital environment. The use of the bolus thrombolytic agent can be seen as a catalyst to increase the eligible patients' access to pharmacological reperfusion in the pre-hospital environment. The modeling has suggested that despite the need for the initial investment and the lower diagnostic accuracy of AMI in the prehospital care group, the total cost of the hypothetical cohort of patients followed for one year was lower compared to the inhospital treatment, with a gain of 0.0035 in 1 year and 0.1585 at the data projection for the time horizon of 20 years. In spite of the higher cost of the bolus thrombolytic agent when compared to streptokinase, the higher effectiveness of the first in the prehospital environment allows the minimization of the costs resulting from complications that are secondary to the delay in the reperfusion of patients with AMI, such as heart failure, reinfarction and the need for a higher number of high-cost interventions.
The analytical model of decision developed by Vale et $\mathrm{al}^{7}$ also indicated the increase in life expectancy of 0.09 years for the prehospital when compared to the life expectancy in the inhospital environment. However, the model by Vale et $\mathrm{al}^{7}$ showed that the authors identified an incremental cost of $£ 61$ per patient, in the prehospital environment.

One limitation of the present study was the need to use probability data of outcomes occurred in another population and different scenarios from that of SUS, although we used a resource estimate and cost analysis adapted to our reality. Another limitation is the absence of the cost estimate necessary to capacitate the prehospital team, such as doctors, nurses and paramedics to treat patients with $\mathrm{AMI}$ and to implement the routine prehospital thrombolysis.

This economic analysis addressed the high-cost treatment of one of the complications of atherosclerotic disease; however, the better correlations between the use of the resource (cost) and the attained clinical benefit (effectiveness) are obtained with the intervention strategies at the primary care, i.e., to fight the more prevalent risk factors to minimize the development of coronary disease.

\section{Conclusion}

We conclude that by adopting the strategy of pre-hospital thrombolysis in AMI, in the public health system scenario with the use of MECS, the early mortality and morbidity can be reduced for these patients. The benefits of intervention health, i.e., the possibility of early reperfusion, can mean a lower cost in the mid-and long-term, due to the decrease in reinfarction and morbidity of the chronic ischemic cardiopathy.

\section{Potential Conflict of Interest}

No potential conflict of interest relevant to this article was reported.

\section{Sources of Funding}

There were no external funding sources for this study.

\section{Study Association}

This study is not associated with any graduation program.

\section{References}

1. Fibrinolitic Therapy Trialists' (FTT) Collaborative Group. Indications for fibrinolytic therapy in suspected acute myocardial infarction: collaborative overview of early mortality and major morbidity results from all randomised trials of more than 1000 patients. Fibrinolytic Therapy Trialists' (FTT) Collaborative Group. Lancet. 1994; 343: 311-22.

2. Wallentin L. Reducing time to treatment in acute myocardial infarction. Eur J Emerg Med. 2000; 7 (3): 217-27.

3. Ministério da Saúde/SVS - Sistema de Informações de Mortalidade (SIM) e IBGE 2003. [acesso em 2007 jan 17]. Disponível em: http://www.datasus. gov.br.

4. Morrison LJ, Verbeek PR, McDonald AC, Sawadsky BV, Cook DJ. Mortality and prehospital thrombolysis for acute myocardial infarction: a meta-analysis. JAMA. 2000; 283 (20): 2686-92.

5. Brasileiro AL. SAMU-192 and the prehospital approach to acute myocardial infarction in Brazil: hope for patients or one more missed opportunity? Arq Bras Cardiol. 2007; 88 (2): e44-6.

6. Hunink MGM, Glasziou PP. Decision making in health and medicine: integrating the evidence and values. London: Cambridge University Press; 2001.

7. Vale L, Steffens $H$, Donaldson C. The costs and benefits of community thrombolysis for acute myocardial infarction: a decision-analytic model. Pharmacoeconomics. 2004: 22 (14): 943-54. 
8. GREAT Group. Feasibility, safety, and efficacy of domiciliary thrombolysis by general practitioners: grampian region early anistreplase trial. GREAT Group. BMJ. 1992; 305 (6853): 548-53.

9. Wallentin L, Goldstein P, Armstrong PW, Granger CB, Adgey AAJ, Arntz HR, et al. Efficacy and safety of tenecteplase in combination with the low-molecularweight heparin enoxaparin or unfractionated heparin in the prehospital setting: the Assessment of the Safety and Efficacy of a New Thrombolytic Regimen (ASSENT)-3 PLUS randomized trial in acute myocardial infarction. Circulation. 2003; 108 (2): 135-42.

10. Sociedade Brasileira de Cardiologia. III Diretriz Sobre Tratamento do Infarto Agudo do Miocárdio. Arq Bras Cardiol. 2004; 83 (supl 4): 3-86.

11. Ministério da Saúde. Banco de preços do Ministério da Saúde. [Acesso em 2007 jan 17]. Disponível em http://dtr2001.saude.gov.br/banco/..

12. Secretaria da Saúde do Estado da Bahia (SESAB). APH móvel - SAMU. Projeto de reorganização do atendimento de urgências e emergências para o Estado da Bahia. [Acesso em 2007 jan 17]. Disponível em http://www.saude.ba.gov. br/samu/PDR\%20e\%20APH\%20Movel.pdf.

13. Instituto Brasileiro de Geografia e Estatística (IBGE). Tábuas completas de Mortalidade. [Acesso em 2007 jan 17]. Disponível em http://www.ibge.gov. br/home/estatistica/populacao/tabuadevida/2005/default.shtm.

14. Oxford Centre for Evidence Based Medicine: projeto diretrizes. [Acesso em 2007 jan 17]. Disponível em http://www.projetodiretrizes.org.br/ projetodiretrizes/textointrodutorio.pdf

15. Van de Werf F, Ardissino D, Betriu A, Cokkinos DV, Falk E, Fox KA Management of acute myocardial infarction in patients presenting with STsegment elevation. The Task Force on the Management of Acute Myocardial Infarction of the European Society of Cardiology. Eur Heart J. 2003; 24 (1): 28-66.

16. Antman EM, Anbe DT, Armstrong PW, Bates ER, Green LA, Hand M, et al. ACC AHA guidelines for the management of patients with ST-elevation myocardial infarction: a report of the ACC/AHA Task Force on practice guidelines (Committee to revise the 1999 guidelines for the management of patients with acute myocardial infarction). Circulation. 2004; 110 (9): e82-292.

17. Armstrong PW, Bogaty P, Buller CE, Dorian P, O'Neill BJ, Canadian Cardiovascular Society Working Group. The 2004 ACC/AHA guidelines: a perspective and adaptation for Canada by the Canadian Cardiovascular Society Working Group. Can J Cardiol. 2004; 20 (11): 1075-9.

18. Avezum A, Piegas LS, Pereira JC. Risk factors associated with acute myocardial infarction in the Sao Paulo metropolitan region: a developed region in a developing country. Arq Bras Cardiol. 2005; 84 (3): 206-13.

19. Murray CJL, Salomon J, Mathers CD, Lopez AD. Summary measures of population health: concepts, ethics, measurement and applications: non serial publications. Geneva; WHO; 2002. 